\title{
TERF2IP Gene
}

National Cancer Institute

\section{Source}

National Cancer Institute. TERF2IP Gene. NCI Thesaurus. Code C112896.

This gene is involved in both telomere maintenance and gene transcription. 